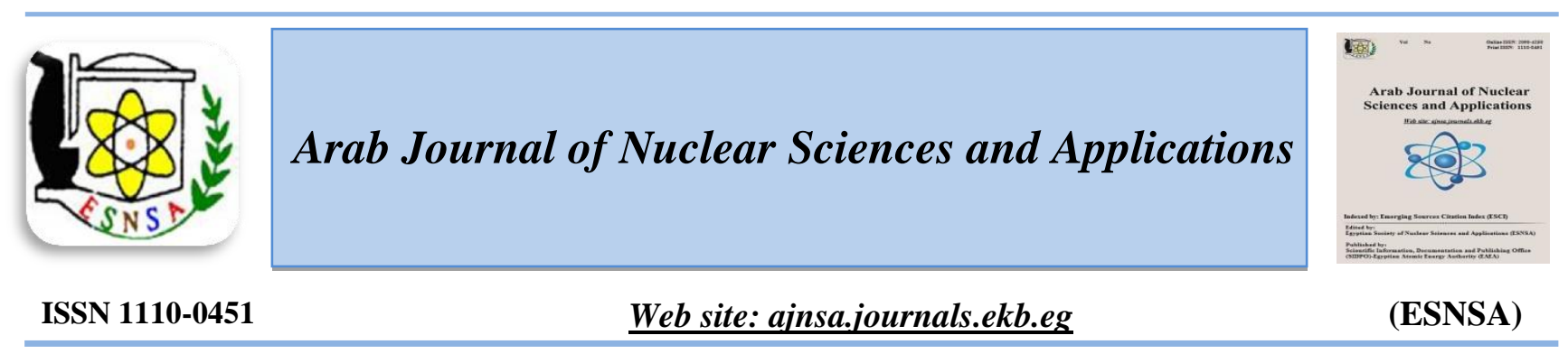

\title{
Leaching and Precipitation of Thorium Ions from Cataclastic Rocks, Abu Rusheid Area, South Eastern Desert, Egypt
}

\author{
S. Y. Afifi ${ }^{1}$, M. Z. Saad ${ }^{2}$, L. A.Yousef ${ }^{1}$ and A. H. Ismail ${ }^{1}$ \\ (1) Nuclear Materials Authority, P.O. Box 530 El Maadi, Cairo, Egypt \\ ${ }^{(2)}$ Chemistry Department, Faculty of Science, Zagazig University, Egypt
}

\begin{abstract}
Received $3^{\text {rd }}$ Jul 2017 The leaching of thorium from representative samples collected from Abu Rusheid area, south Eastern Accepted $3^{\text {rd }}$ Sep 2017 Desert, Egypt using sulphuric acid has been studied. Factors affecting the leaching of thorium were investigated such as, acid type, $\mathrm{S} / \mathrm{L}$ ratio, $\mathrm{H}_{2} \mathrm{SO}_{4}$ concentration, leaching time, temperature and grain size. The best conditions for leaching of thorium were, $\mathrm{H}_{2} \mathrm{SO}_{4}$ acid as the best acid, $\mathrm{S} / \mathrm{L}$ ratio of 1:5, 3.0 $\mathrm{M} \mathrm{H}_{2} \mathrm{SO}_{4}, 2.0$ hour of leaching time, -200 mesh size at $90^{\circ} \mathrm{C}$. After leaching, the mixture was filtrated then divided into two parts the leach liquor and the residue. The leach liquor was adjusted at $\mathrm{pH} 1.0 \mathrm{by}$ ammonia solution and addition $10 \%$ oxalic acid. The precipitate obtained was filtrated and dried at $120^{\circ} \mathrm{C}$ for 1 hour. The obtained precipitate showed $91.60 \%$ of thorium content when using $3.0 \mathrm{M} \mathrm{H}_{2} \mathrm{SO}_{4}$ acid. The quality of the precipitate was confirmed by XRF.
\end{abstract}

Keywords: Thorium / Leaching / Arsenazo III / XRF

\section{Introduction}

Abu Rusheid area lies in the southern part of the Eastern Desert of Egypt, along the lower reaches of Wadi Abu Rusheid. It is located about $45 \mathrm{Km}$ southwest of Marsa Alam between latitude $24^{\circ} 36$ $43^{\prime \prime}$ and $24^{\circ} 38^{\prime} 26^{\prime \prime} \mathrm{N}$ and longitude $34^{\circ} 46^{\prime} 0^{\prime \prime}$ and $34^{\circ} 46^{\prime} 35^{\prime \prime}$ E. The area could be reached from the Red Sea coast through Wadi Al Gemal and then Wadi Nugrus along a desert track about $40 \mathrm{Km}$ long.

Thorium is a soft, paramagnetic, bright silvery radioactive actinide metal and its most important oxidation state is +4 , represented in compounds such as $\mathrm{ThO}_{2}$ and $\mathrm{ThF}_{4}$. It is found in several minerals, including thorianite (up to $90 \% \mathrm{ThO}_{2}$ ), monazite $\left(1-15 \% \mathrm{ThO}_{2}\right)$ and thorite (up to $80 \%$ $\mathrm{ThO}_{2}$ ). These minerals are less abundant compared to uranium because thorium does not form secondary minerals. They occur principally in granites and pegmatites, all thorium minerals contain some uranium, just as all primary uranium minerals contain some thorium. Thorium is a nuclear_element and is used as a source for nuclear power and as coating material for tungsten wire found in electronic equipment.

The Egyptian black sand beach deposits are the main thorium ore in Egypt due to the presence of monazite [1]. In Egypt, the thorium content in monazite can attain up to $30 \%$ and the Egyptian monazite assays $5.8 \% \mathrm{ThO}_{2}$. Large deposits of thorium are found in Australia, India, Norway and the United States and about 30,000 metric tons are extracted each year.

Abu Rusheid- Sikeit area has been studied by several authors [2-6] who reported that the exposed rocks in this area include ophiolitic rocks, ophiolitic melange, cataclstic rocks and intrusive

Corresponding Author: dr_sofia2002@yahoo.co.uk

DOI: $10.21608 /$ ajnsa.2018.6506

(C) Scientific Information, Documentation and Publishing Office (SIDPO)-EAEA 
rocks. The Abu Rusheid area is characterized by containing numerous mineralizations, so it can be called a poly mineralization area. The mineralization included: uranium minerals autunite, coeffinite, carnolite, uranophane and $\beta$ uranophane. Thorium minerals were represented as uranothorite, thorite, cheralite and thorianite. Niobium minerals zinc, manganese minerals, base metals associated minerals such as zircon, monazite and xenotime are also present.

The leaching or dissolution of thorium is carried out through conventional or non-conventional techniques depending on the type of thorium minerals, the ore grade, the economy of the process and the environmental impact.

There is an economic technique for separation and purification of thorium from their hydrous oxide cake concentrate, which could be obtained by alkali treatment of Egyptian monazite sand [7]. The extraction from nitric acid medium used tributoxyethyl phosphate (TBEP) in $n$-paraffin [8] and trioctyl - phosphine oxide (TOPO) dissolved in cyclohexane and determination of thorium was by thoron [9]. The process of thorium extraction from sulphuric acid liquor generated from the chemical monazite treatment through a solvent extraction technique has been reported [10]. Thorium and uranium were separated from the nitrate medium using ion exchange Amberlite CG400 and then determined using ICP-MS [11], or triphenylphosphine oxide (TPPO) [12].

The main objective of this paper is to study the optimum conditions for leaching thorium from cataclastic rocks and its precipitation as thorium oxalate.

\section{Experimental}

\section{Chemicals and reagents}

All the chemicals and reagents used in this work were of analytical reagent grade (AR). Double distilled water was used for preparation of all aqueous solutions and for dilution. Thorium stock solution was prepared by dissolving $2.38 \mathrm{~g}$ of $\mathrm{Th}\left(\mathrm{NO}_{3}\right)_{4} \cdot 4 \mathrm{H}_{2} \mathrm{O}$ in $1000 \mathrm{ml}$ double distilled water to get a fixed concentration of $1000 \mathrm{ppm}$.

\section{Instrumentation and equipment}

All samples and reagents used in this work were weighed using a precise balance of precise type
Schimadzu AY 220, with stability of sensitivity of $10^{-4} \mathrm{~g}$ and an accuracy of $\pm 0.01 \%$. A bench $\mathrm{pH}$ meter of Inolab digital $\mathrm{pH}$ meter, level 1.0 (England) was used for measuring all $\mathrm{pH}$ values of the different solutions in the $\mathrm{pH}$ range $0.00-14.00$ with resolution of $0.01 \mathrm{pH}$ and accuracy \pm 0.01 . The scale of the $\mathrm{pH}$ meter was calibrated before each experiment using a standard buffer solution at ambient room temperature $22 \pm 1^{\circ} \mathrm{C}$. Double distilled water was used for preparing all standard solutions and reagents.

The absorbance of the investigated solution and Th , $\mathrm{SiO}_{2}, \mathrm{Al}_{2} \mathrm{O}_{3}, \mathrm{TiO}_{2}, \mathrm{P}_{2} \mathrm{O}_{5}$ was measured by using the Metertech Inc, model SP-8001, UV-visible spectrophotometer. This apparatus is a single beam recording spectrophotometer with a wavelength range from 200 to $1100 \mathrm{~nm}$ with an accuracy of $\pm 1 \mathrm{~nm} .5 .0 \mathrm{~cm}^{3}$ quartz cells with a path length of $1.0 \mathrm{~cm}$ were used for the sample and blank. Sodium and potassium were determined by a Sherwood flame photometer model 410 (England), using a series of chemical solutions. The analysis of $\mathrm{CaO}, \mathrm{MgO}$ and $\mathrm{Fe}_{2} \mathrm{O}_{3}$ were determined by titration [13].

\section{Measurements}

The unknown minerals were identified by using Xray diffraction (XRD). The equipment used is the PHILIPS unit pw 3710/31 diffractometer with an automatic sample changer pw-1775, 21 position scintillation counter, $\mathrm{Cu}$ - target tube and $\mathrm{Ni}$ filter at $40 \mathrm{kV}$ and $30 \mathrm{MA}$.

Trace elements such as $\mathrm{V}^{5+}, \mathrm{Cr}^{3+}, \mathrm{Ni}^{2+}, \mathrm{Co}^{2+}, \mathrm{Zn}^{2+}$ $, \mathrm{Ga}^{3+}, \mathrm{Rb}^{+}, \mathrm{Sr}^{2+}, \mathrm{Y}^{3+}, \mathrm{Zr}^{4+}, \mathrm{Nb}^{5+}, \mathrm{Pb}^{2+}$ and $\mathrm{Ba}^{2}$ were measured using $\mathrm{X}$-ray fluorescence (XRF). This equipment is a (PHILIPS) unit with automatic sample changer PW 1510, connected to a computer system using X-40 program for spectroscopy with the detection limit of $5.0 \mathrm{ppm}$. All measurements were performed at the Nuclear Materials Authority (NMA), Cairo, Egypt. Different concentrations of thorium were prepared by dilution. Thorium concentration was measured colorimetrically using Arsenazo III complex [14].

For determination of the concentration of thorium in the samples, the following procedure was carried out to reduce the effect of most interfering ions. One gram of the sample was put in a breaker and $10 \mathrm{ml}$ of $4.0 \mathrm{~N} \mathrm{HNO}_{3}$ were added. The mixture 
was evaporated to near dryness on a hot plate. This was followed by the addition of $2.0 \mathrm{ml}$ conc. $\mathrm{H}_{2} \mathrm{SO}_{4}$ and evaporation to dryness on a hot plate, then 50 $\mathrm{ml}$ water was added to the dried sample, and heated to a boiling point for five minutes. After cooling, the solution was filtered then the thorium was measured using Arsenazo Ш method.

\section{Results and Discussion Characterization}

The studied samples were completely attacked using a mixture of acids $\mathrm{HF}, \mathrm{HNO}_{3}, \mathrm{HClO}_{4}$ and $\mathrm{HCl},[13]$ to determine the chemical composition of major oxides of the studied samples (cataclastic rock) which were collected from Abu Rusheid area, south Eastern Desert, Egypt (Table 1).

The thorium content in the sample was extracted at optimum conditions; $1.0 \%$ DEHPA dissolved in cyclohexane, A:O ratio 1:1, pH 1.0 and shaking time 3.0 minutes at ambient room temperature $\left(22 \pm 1^{\circ} \mathrm{C}\right)$, while the stripping process was carried out on the loaded organic phase under optimum conditions; $2 \mathrm{M}$ sulfuric acid, $\mathrm{A}: \mathrm{O}$ ratio $2: 1, \mathrm{pH}$ 1.0 and shaking time 3.0 minutes at ambient room temperature, the results are listed in (Table 2).

$\mathrm{X}$ - ray Fluorescence technique (XRF) was used to detect the trace elements present in the studied samples collected from Abu Rusheid area, south Eastern Desert, Egypt, (Table 3).

X-ray diffraction data of geologic samples collected from Abu Rusheid area, south Eastern Desert, Egypt indicated the presence of Xenotime $\left(\mathrm{YPO}_{4}\right)$, Zinnwaldite $\left(\mathrm{KLiFeAl}\left(\mathrm{AlSi}_{3}\right) \mathrm{O}_{10}(\mathrm{OH}, \mathrm{F})_{2}\right)$ and Thorite (Th,U)SiO 4 ), (Table 4).

\section{Leaching investigations}

The leaching process can be classified into two major methods, namely conventional or nonconventional techniques. The conventional method is the agitation technique for both acidic and alkaline leaching, while non-conventional one includes: pressure, bacterial, natural, chlorination and fluorination leaching.

The acid leaching method is characterized by its low cost, short leaching time, high extraction efficiency, availability and excellent impurities removal. A series of experiments were carried out to study the selective dissolution of thorium from the cataclastic rock. Different parameters that affect the leaching of thorium were studied such as; acid type, $\mathrm{H}_{2} \mathrm{SO}_{4}$ concentration, $\mathrm{S} / \mathrm{L}$ ratio, leaching time, temperature and grain size.

\section{Effect of leaching acid}

To choose which acid type is the best for leaching thorium, several acid leaching experiments were tested using $\mathrm{H}_{2} \mathrm{SO}_{4}, \mathrm{HCl}, \mathrm{H}_{3} \mathrm{PO}_{4}$ and $\mathrm{HNO}_{3}$ acids as the leaching agent. The data given in Figure (1) indicate that sulphuric acid was the best leaching agent $(91.95 \%)$ to leach thorium if compared with $\mathrm{HCl}(86.19 \%), \mathrm{H}_{3} \mathrm{PO}_{4}(68.96 \%)$ and $\mathrm{HNO}_{3}(83 \%)$ under the same experimental conditions.

\section{Effect of $\mathrm{H}_{2} \mathrm{SO}_{4}$ concentration}

The effect of sulphuric acid as the leaching agent was investigated using different concentrations ranging from $1.0 \mathrm{M}$ to $6.0 \mathrm{M}$, while other leaching parameters were kept constant. The obtained results indicate that the best acid concentration of sulphuric acid is $3.0 \mathrm{M}$ which was found to give the highest leaching efficiency, 91.95\%, (Fig.2).

\section{Effect of solid/ liquid ratio (S/L).}

The effect of $\mathrm{S} / \mathrm{L}$ ratio on leaching of thorium was studied through the range between 1:4 to 1:20, while fixing the other parameters. The obtained results show that the leaching of thorium increased gradually from the ratio $1: 4$ to $1: 5$ after that it remained constant till the ratio 1:20; therefore, the best solid / liquid ratio which leached $91.95 \%$, was found to be 1:5 (Fig.3).

\section{Effect of leaching time}

To study the effect of leaching time on thorium leaching, different leaching times in the range 1.0 hour to 3.5 hour were performed, while the other leaching conditions were kept fixed. The results show that the leaching efficiency increased from 1.0 hour till 2 hours $(94.82 \%)$ and after 2.0 hours, it remained constant. Therefore, the best leaching time was found to be 2.0 hours, (Fig. 4).

\section{Effect of temperature}

Temperature plays a vital role which determines the reaction way, whether it is exothermic or endothermic and also may accelerate or slowdown the reaction. The effect of temperature on thorium leaching efficiency was studied by varying the temperature from room temperature, about 
$22 \pm 1^{\circ} \mathrm{C}, \quad$ to $110^{\circ} \mathrm{C}$. It was noticed that, the leaching efficiency $(\%)$ of thorium increased with increasing the temperatures and reached its maximum at $90{ }^{\circ} \mathrm{C}$ which dissolved $94.82 \%$ of thorium. At higher temperatures, the leaching efficiency decreased which can be related to evaporation, semi dryness of the matrix and breakdown for the material [15].

\section{Effect of mineral grain size}

In the present study, the samples were ground to particle size, -12 mesh $(1.7 \mathrm{~mm})$ to -230 mesh $(-0.063 \mathrm{~mm})$. To study the effect of grain size on thorium leaching efficiency, a series of experiments were carried out using different grades of the rock sample having grain size ranging from -12 mesh to -230 mesh, while the other leaching conditions were kept fixed. The results indicated that the highest thorium leaching efficiency reached was $94.82 \%$ with fine grain size -200 mesh, while lower size had much less thorium leaching efficiency, (Fig.6).

\section{Proposed flow sheet}

According to the obtained results, the following flow sheet was proposed for the recovery of thorium. In this case, $100 \mathrm{~g}$ of the representative samples with particle size -200 mesh was subjected to acid leaching at the following optimum conditions: $3.0 \mathrm{M} \mathrm{H}_{2} \mathrm{SO}_{4}$ acid with ratio 1:5 (S/L) for 2.0 hours at $90^{\circ} \mathrm{C}$.

The solution was filtered and divided into two parts namely, the filtrate (leach liquor) and the residue. The thorium leach liquor was adjusted to $\mathrm{pH} 1.0$ by ammonia solution then $10 \%$ oxalic acid was added. The precipitate obtained was filtrated and dried at $120^{\circ} \mathrm{C}$ for 1 hour. The precipitate shows that $91.6 \%$ of thorium was formed by leaching with 3.0M H $\mathrm{H}_{2} \mathrm{SO}_{4}$ acid, (Fig.7).

The final product of thorium was identified by $\mathrm{X}$ ray fluorescence (XRF), [Philips experimental unit with automatic sample changer PW 1510, (JEOLJSX-3222 Element Analyzer) connected to a computer system using X-40 program for spectroscopy with the detection limit $5.0 \mathrm{ppm}$, Atomic Energy Authority, Cairo, Egypt]. X-ray diffraction (XRD) showed that, the precipitate contains mainly $91.6 \%$ thorium which confirms our investigation. The main impurities are $\mathrm{Y}, \mathrm{Ce}$, $\mathrm{Yb}, \mathrm{U}, \mathrm{Ca}$ and... (Fig.8).

\section{Conclusion}

The present study shows that thorium can be leached from cataclastic rocks using sulphuric acid under suitable leaching conditions. It was found that, the best leaching conditions for representative samples collected from Abu Rusheid area, south Eastern Desert, Egypt are 3.0 M H2SO4 acid, S/L ratio of 1:5, -200 mesh size and 2.0 hours of leaching time at $90 \mathrm{oC}$. The obtained precipitate showed that $91.6 \%$ of thorium could be present under optimum conditions using 3.0M H2SO4 acid. The final precipitate was confirmed by XRF measurements.

Table (1): Chemical analysis of major oxides in (wt \%)

\begin{tabular}{|c|c|c|c|}
\hline Oxides\% & Sample No. & $\mathbf{A}^{*}$ & B $^{*}$ \\
\hline \multirow{13}{*}{ تُنْ } & $\mathrm{SiO}_{2}$ & 67.20 & 67.20 \\
\hline & $\mathbf{A l}_{2} \mathbf{O}_{3}$ & 13.21 & 14.10 \\
\hline & $\mathrm{TiO}_{2}$ & 0.46 & 0.44 \\
\hline & $\mathrm{Fe}_{2} \mathrm{O}_{3}{ }^{\mathrm{T}}$ & 5.60 & 5.60 \\
\hline & $\mathrm{CaO}$ & 1.40 & 2.80 \\
\hline & $\mathrm{MgO}$ & 1.00 & 1.00 \\
\hline & $\mathrm{Na}_{2} \mathrm{O}$ & 5.55 & 5.06 \\
\hline & $\mathbf{K}_{2} \mathbf{O}$ & 1.54 & 1.94 \\
\hline & $\mathbf{P}_{2} \mathbf{O}_{5}$ & 0.38 & 0.31 \\
\hline & $110^{\circ} \mathrm{C}$ & 0.33 & 0.21 \\
\hline & $550^{\circ} \mathrm{C}$ & 0.66 & 0.45 \\
\hline & $1000^{\circ} \mathrm{C}$ & 1.64 & 1.05 \\
\hline & otal (\%) & 98.97 & 100.16 \\
\hline
\end{tabular}

\footnotetext{
* Average means of 10 samples
} 
Table (2): Determination of thorium after extraction and stripping process

\begin{tabular}{|c|c|c|c|c|c|c|c|c|}
\hline \multirow{3}{*}{ 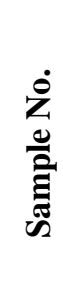 } & & & \multicolumn{2}{|c|}{ Extraction process } & \multicolumn{4}{|c|}{ Stripping process } \\
\hline & \multirow{2}{*}{\multicolumn{2}{|c|}{$\begin{array}{c}\text { Thorium content } \\
\text { (ppm) }\end{array}$}} & \multirow[b]{2}{*}{ 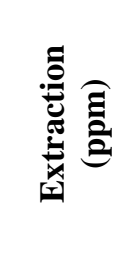 } & \multirow[b]{2}{*}{ 氖 } & \multicolumn{2}{|c|}{ First cycle } & \multicolumn{2}{|c|}{ Second cycle } \\
\hline & & & & & 点 & 象 & 最彎 & 竞 \\
\hline \multirow{3}{*}{$\mathbf{A}^{*}$} & 5505 & & & & & & & \\
\hline & $\begin{array}{l}5506 \\
5508\end{array}$ & 5506 & 5158 & 93.67 & 4683 & 90.79 & 380 & 7.36 \\
\hline & 5491 & & & & & & & \\
\hline B $^{*}$ & $\begin{array}{l}\mathbf{5 4 9 3} \\
\mathbf{5 4 9 5} \\
\end{array}$ & 5493 & 5113 & 93.08 & 4715 & 92.21 & 316 & 6.18 \\
\hline
\end{tabular}

* Average means of 10 samples

Table (3): Trace elements content (ppm) using XRF technique

\begin{tabular}{|c|c|c|}
\hline 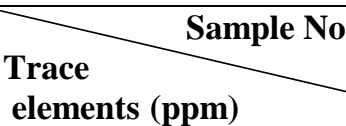 & $\mathbf{A}^{* *}$ & $\mathbf{B}^{* *}$ \\
\hline $\mathrm{Cr}$ & 35 & 33 \\
\hline $\mathbf{N i}$ & 7 & 8 \\
\hline $\mathrm{Cu}$ & 89 & 87 \\
\hline $\mathbf{Z n}$ & 853 & 1183 \\
\hline $\mathbf{Z r}$ & 475 & 752 \\
\hline $\mathbf{R b}$ & 4.33 & 487 \\
\hline $\mathbf{Y}$ & 48 & 58 \\
\hline Ba & 150 & 259 \\
\hline $\mathbf{P b}$ & 85 & 152 \\
\hline $\mathrm{Sr}$ & 1892 & 2435 \\
\hline Ga & 42 & 57 \\
\hline V & 3 & 7 \\
\hline $\mathbf{N b}$ & 35 & 55 \\
\hline$*$ Th & 5506 & 5493 \\
\hline$* \mathbf{U}$ & 2238 & 1928 \\
\hline$* \sum$ REES & 6791 & 7778 \\
\hline
\end{tabular}

* Determination by spectrophotometer

** Average means of 10 samples 
Table (4): X-ray diffraction data of the studied geologic samples (cataclastic rocks), Abu Rusheid area, south Eastern Desert, Egypt

\begin{tabular}{|c|c|c|c|c|c|c|c|}
\hline \multicolumn{2}{|c|}{$\begin{array}{l}\text { Identified } \\
\text { Sample }\end{array}$} & \multicolumn{2}{|c|}{$\underset{\mathrm{YPO}_{4}}{\text { Xenotime }}$} & \multicolumn{2}{|c|}{$\begin{array}{c}\text { Zinnwaldite } \\
\mathrm{KLiFe} \mathrm{Al}\left(\mathrm{AlSi}_{3}\right) \mathrm{O}_{10}(\mathrm{OH}, \mathrm{F})_{2}\end{array}$} & \multicolumn{2}{|c|}{$\begin{array}{l}\text { Thorite } \\
(\mathrm{Th}, \mathrm{U}) \mathrm{SiO}_{4}\end{array}$} \\
\hline $\mathbf{d A}^{\mathbf{0}}$ & $\mathbf{I} / \mathbf{I}^{\mathbf{o}}$ & $\mathbf{d} \mathbf{A}^{\mathbf{o}}$ & $\mathbf{I} / \mathbf{I}^{\mathbf{0}}$ & $\mathbf{d} \mathbf{A}^{\mathbf{o}}$ & $\mathbf{I} / \mathbf{I}^{\mathbf{o}}$ & $\mathbf{d} \mathbf{A}^{\mathbf{o}}$ & $\mathbf{I} / \mathbf{I}^{\mathbf{0}}$ \\
\hline 9.87 & 9 & & & 9.90515 & 98 & & \\
\hline 4.71 & 10 & & & & & 4.72 & 85 \\
\hline 4.54 & 11 & 4.55 & 25 & 4.51621 & 1 & & \\
\hline 3.44 & 100 & 3.45 & 100 & & & 3.55 & 100 \\
\hline 3.34 & 23 & & & 3.34698 & 4 & & \\
\hline 3.30 & 25 & & & 3.30191 & 100 & & \\
\hline 2.87 & 3 & 2.75 & 9 & 2.89595 & 7 & 2.84 & 45 \\
\hline 2.66 & 4 & & & 2.67656 & 4 & 2.67 & 75 \\
\hline 2.56 & 15 & 2.56 & 50 & & & 2.52 & 30 \\
\hline 2.43 & 5 & 2.44 & 13 & & & & \\
\hline 1.98 & 7 & & & 1.98151 & 2 & & \\
\hline 1.92 & 46 & 1.929 & 9 & & & & \\
\hline 1.82 & 6 & 1.824 & 13 & & & 1.83 & 65 \\
\hline 1.76 & 12 & 1.768 & 50 & & & 1.76 & 25 \\
\hline 1.72 & 15 & 1.925 & 18 & & & & \\
\hline 1.60 & 2 & 1.616 & 3 & & & & \\
\hline 1.54 & 3 & 1.543 & 9 & & & 1.54 & 20 \\
\hline 1.44 & 2 & 1.432 & 9 & & & & \\
\hline \multicolumn{2}{|c|}{ ASTM Card No. } & \multicolumn{2}{|c|}{ 011-0254 } & \multicolumn{2}{|c|}{ 041-1482 } & \multicolumn{2}{|c|}{$11-419$} \\
\hline
\end{tabular}

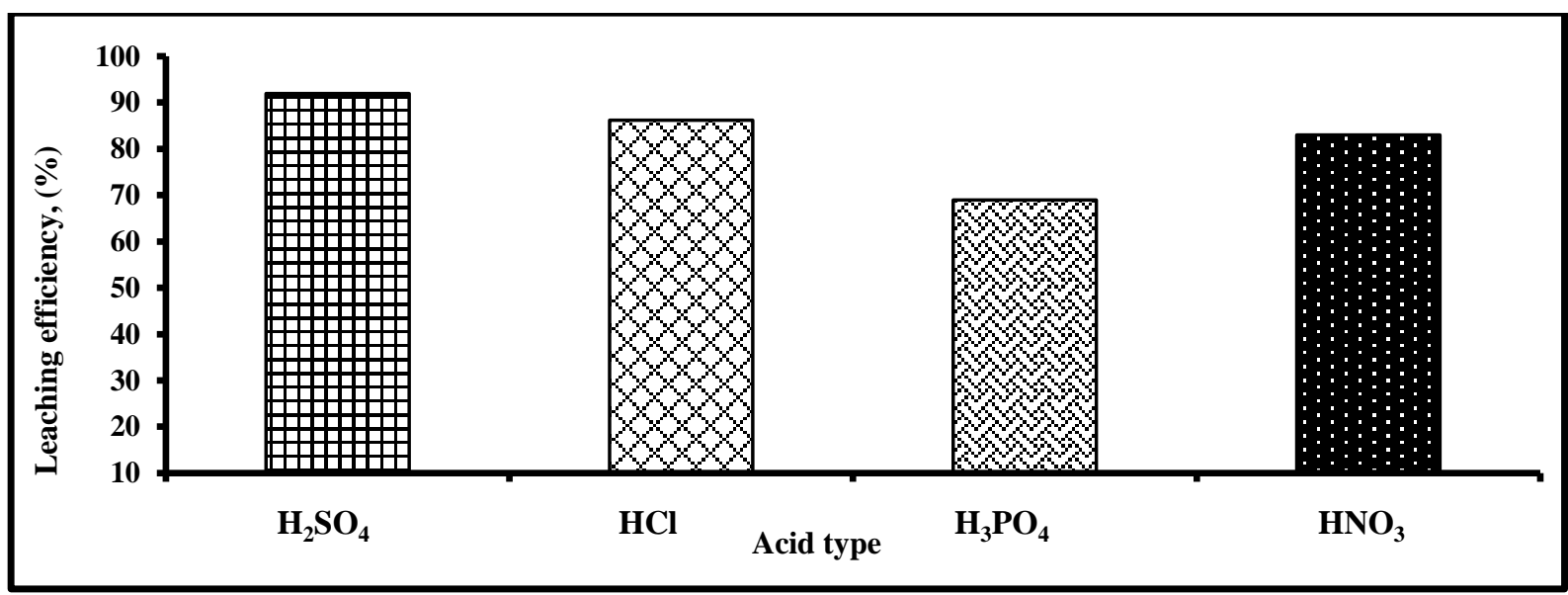

Fig. (1): Effect of different acid types on thorium leaching efficiency $(\%)$

Leaching conditions for thorium: Temperature $\left(90^{\circ} \mathrm{C}\right)$, acid concentration $(5.0 \mathrm{M})$, phase ratio S/L: $1 / 5$ and leaching time 1.0 hour. 


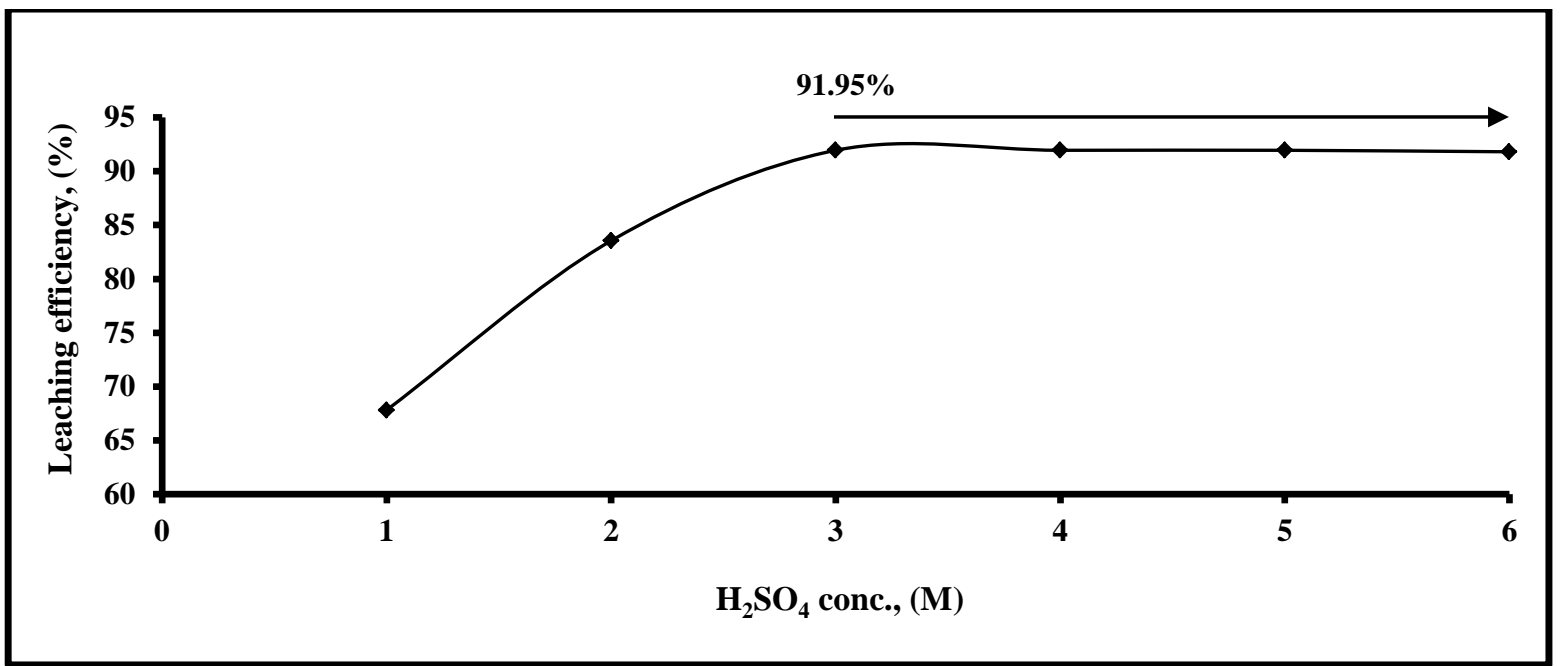

Fig. (2): Effect of $\mathrm{H}_{2} \mathrm{SO}_{4}$ concentration on thorium leaching efficiency (\%)

Leaching conditions for thorium: $\mathrm{H}_{2} \mathrm{SO}_{4}$ acid, $\mathrm{S} / \mathrm{L}: 1 / 5$, temperature $\left(90^{\circ} \mathrm{C}\right)$ and leaching time 1.0 hour.

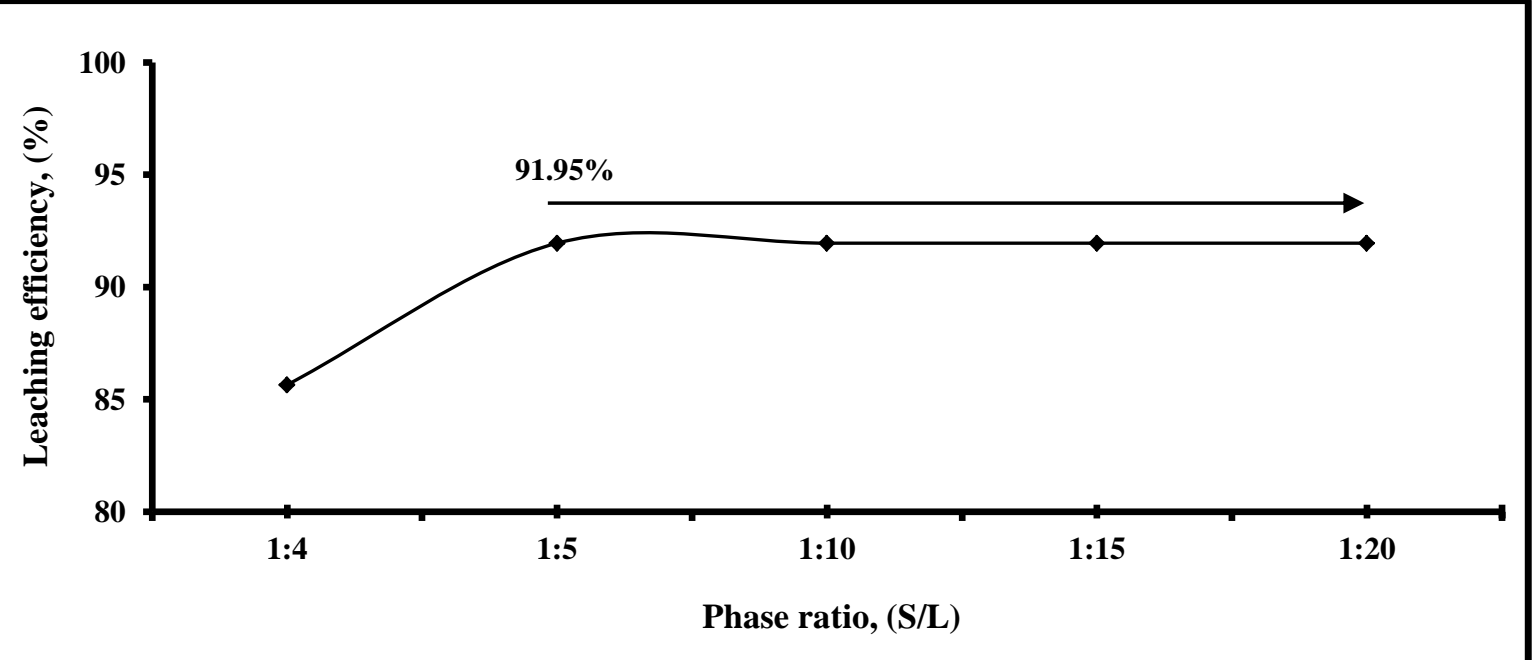

Fig. (3): Effect of phase ratio (S/L) on thorium leaching efficiency (\%)

Leaching conditions for thorium:3.0 $\mathrm{M} \mathrm{H}_{2} \mathrm{SO}_{4}$ acid, temperature $\left(90^{\circ} \mathrm{C}\right)$, and leaching time 1.0 hour. 


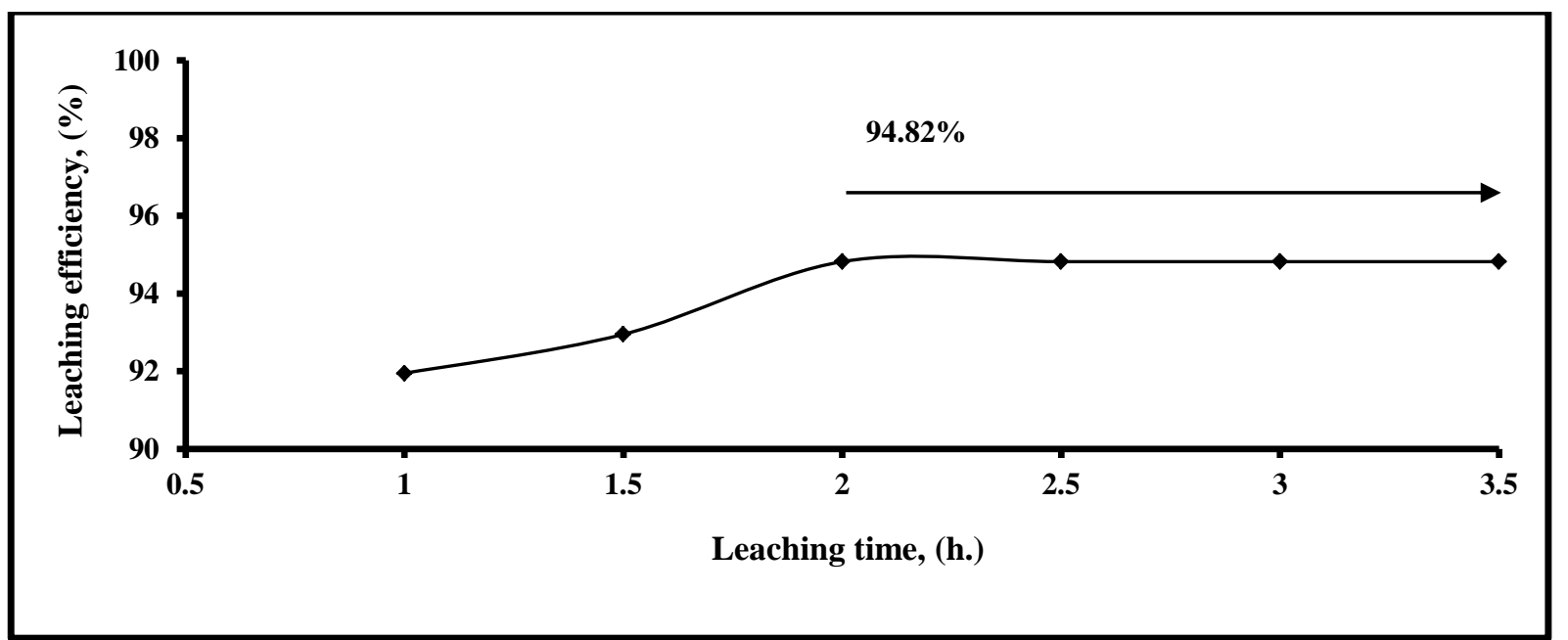

Fig. (4): Effect of leaching time on thorium leaching efficiency (\%)

Leaching conditions for thorium:3.0 $\mathrm{M} \mathrm{H}_{2} \mathrm{SO}_{4}$ acid, temperature $\left(90^{\circ} \mathrm{C}\right)$ and $\mathrm{S} / \mathrm{L}: 1 / 5$.

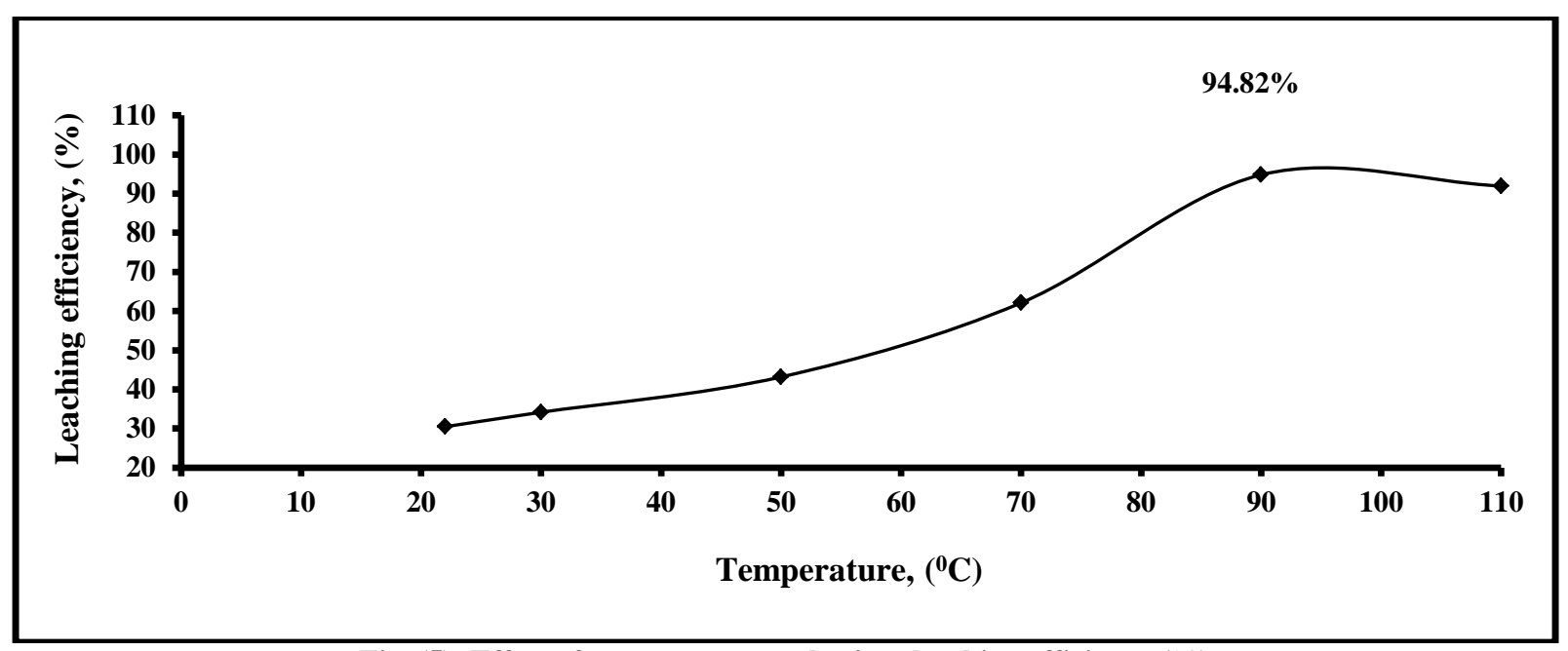

Fig. (5): Effect of temperature on thorium leaching efficiency (\%)

Leaching conditions for thorium: $3.0 \mathrm{M} \mathrm{H}_{2} \mathrm{SO}_{4}$ acid, temperature $\left(90^{\circ} \mathrm{C}\right), \mathrm{S} / \mathrm{L}: 1 / 5$ and leaching time 2.0 hour.

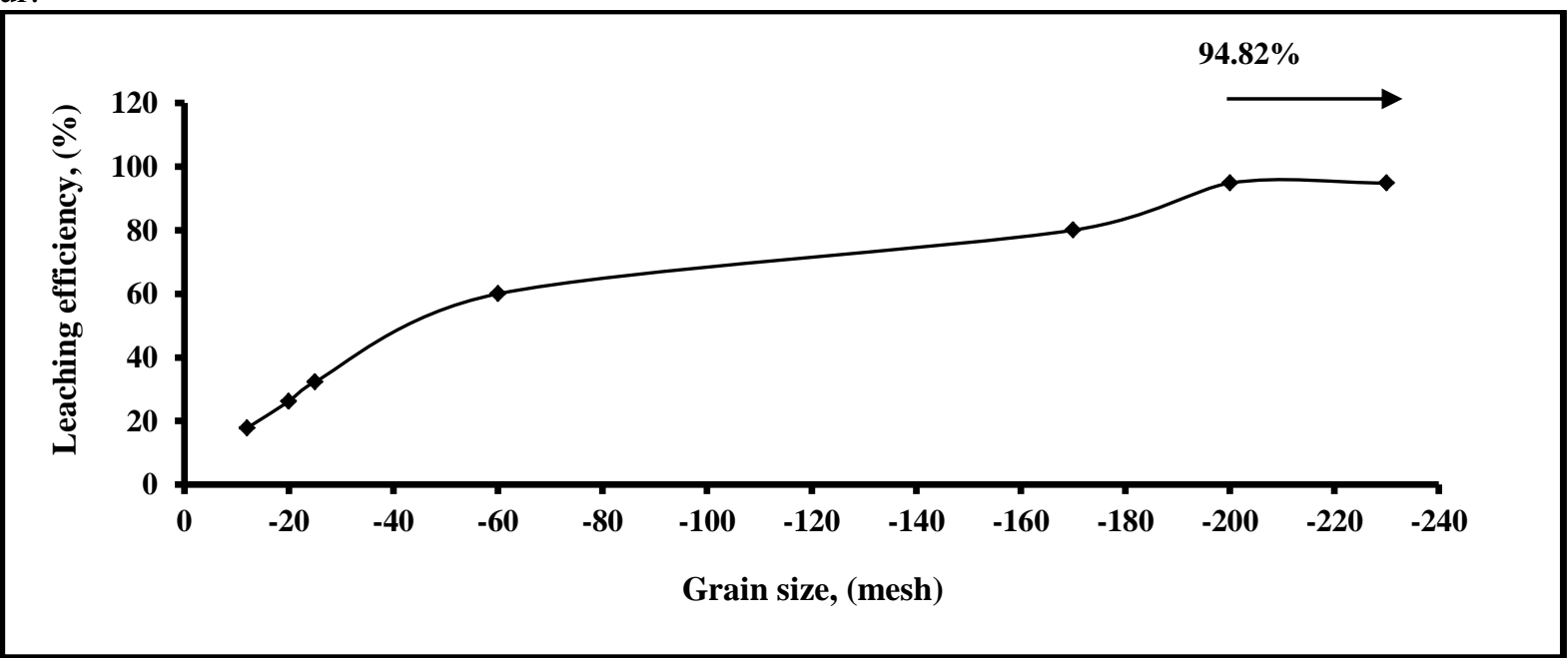

Fig. (6): Effect of grain size on thorium leaching efficiency (\%)

Leaching conditions for thorium: $3.0 \mathrm{M} \mathrm{H}_{2} \mathrm{SO}_{4}$ acid, temperature $\left(90^{\circ} \mathrm{C}\right), \mathrm{S} / \mathrm{L}: 1 / 5$ and leaching time 2.0 hour. 


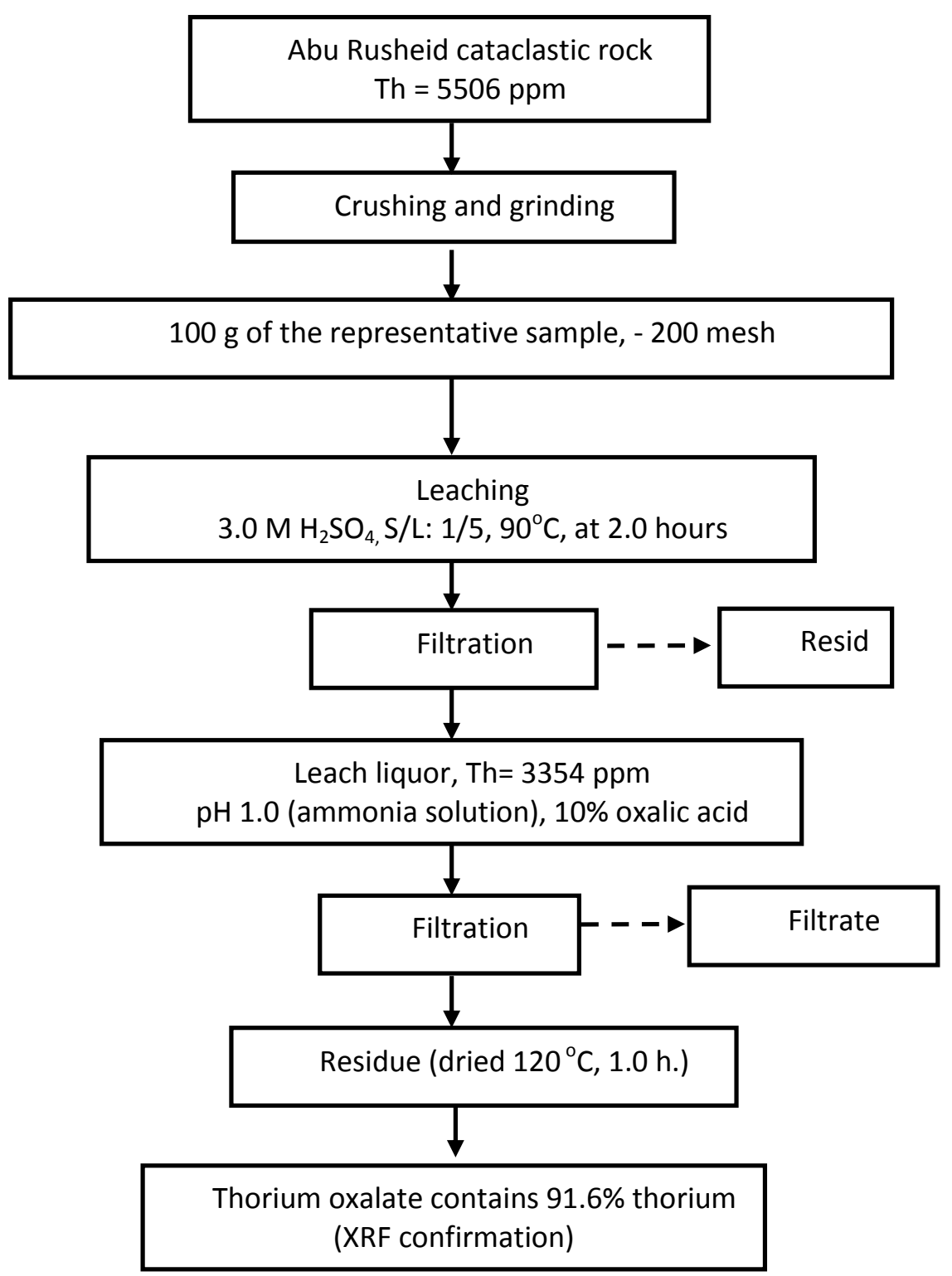

Fig. (7): Proposed flow sheet for leaching thorium with 3.0 $\mathrm{M} \mathrm{H}_{2} \mathrm{SO}_{4}$ from the representative samples (cataclastic rocks), Abu Rusheid area, south Eastern Desert, Egypt 


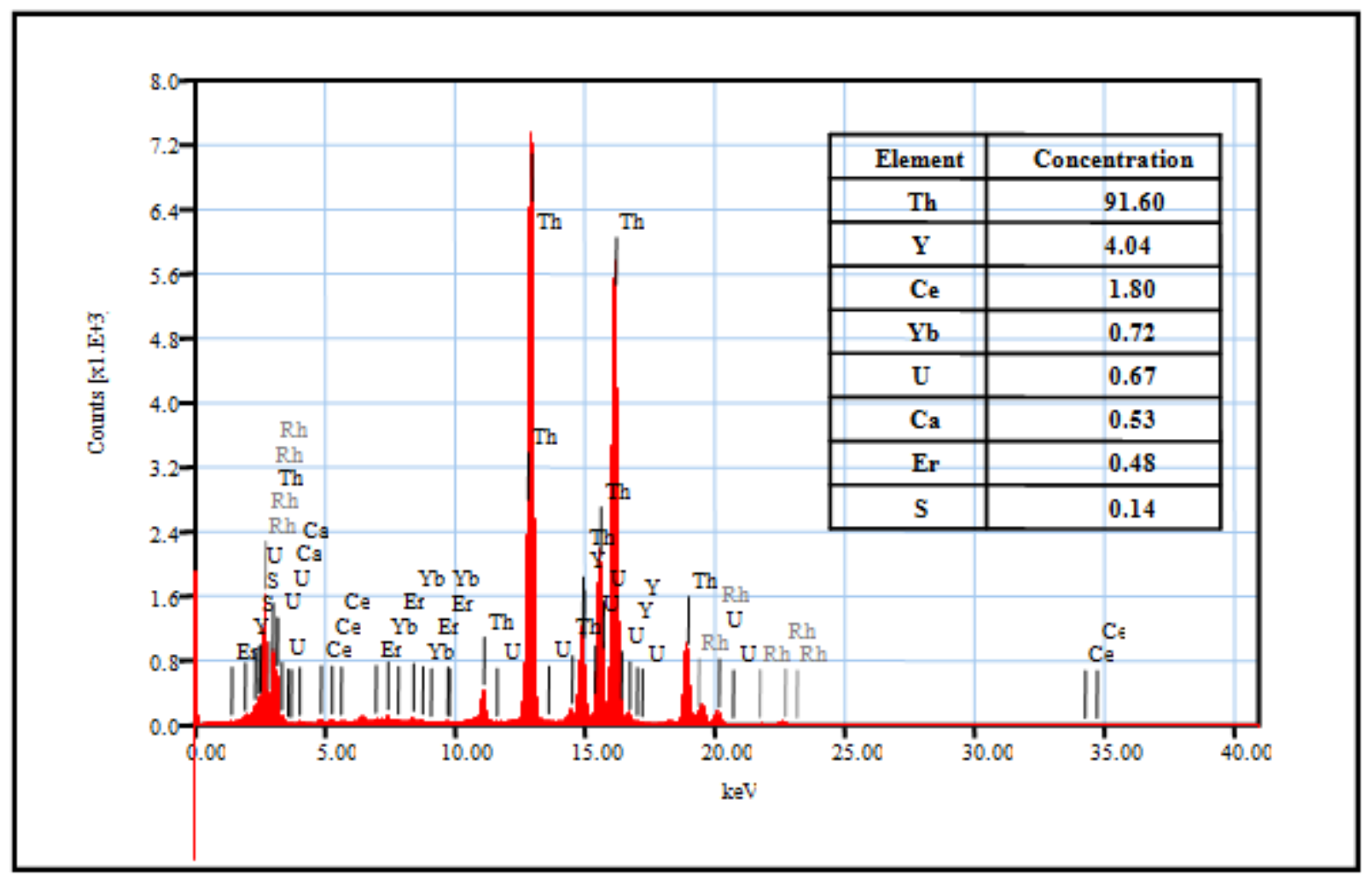

Fig. (8): XRF analysis of separated thorium from geological samples (cataclastic rocks), Abu Rusheid area, south Eastern Desert, Egypt

\section{References}

1- Y.A. El-Nadi, J.A. Daoud and H.F. Aly; Int. J. Miner Process; 76, 101 (2005).

2- G.M. Saleh; The potentiality of uranium in Wadi Nugrus area, south Eastern Desert, Egypt; Ph. D. Thesis Mans. Univ. (1997).

3- H.S. Assaf, M.E. Ibrahim, A.A. Zalata, A.A. ElMetwally and G.M. Saleh;Earth Sci.; 12,6, (2000).

4- M.E. Ibrahim, G.M. Saleh, T. Amer, F.O. Mahmoud, A.A. Abu El Hassan, I.H. Ibrahim, M.A. Aly,M.S. Azab, M.A. Rashed, F.M. Khaleal and M.A. Mahmoud; Uranium and associated rare metals Potentialitiesof Abu Rusheid brecciated shear zone II South Eastern Desert,Egypt (internal report); (2004).

5- M.E. Ibrahim, G.M. Saleh, M.A. Hassan, M.M. El Tookhi and M.A. Rashed; Geochemistry of lamprophyres uranium mineralization, Abu Rusheid area, South Eastern Desert, Egypt; The 10 inter. Min. petrol., Metall. Engin. Conf., Assiut Univ.; 3-5 Dec.; 41 (2007).

6- M.E. Ibrahim, A.A. Abd Al Wahed, M.A. Rashed, F.M. Khaleal, G.M. Mansour and K. Watanabe; Comparative study between alkaline and calc alkaline lamprophyres, Abu Rusheid area, South Eastern Desert, Egypt, The $10^{\text {th }}$. Min. petrol., Metall. Engin. Conf., Assiut Univ.; 3-5 Dec.; 99 (2007).
7- N.S. Hammad; Physical and thermal treatment of phosphate ores, M.Sc. Thesis, Faculty of Science, Cairo University, (1966).

8- S. Biswas, K.N. Hareendran, D. K. Singh, J. N. Sharma and S. B. Roy; Radioanal. Nucl. Chem.; 283, 668 (2010).

9- S.Y. Afifi, M. M. Mustafa, E. M. El Sheikh and M.A.S. Gado; Arab Journal of Nuclear Sciences and Applications; 45, 16 (2012).

10- J.C. Amaral and C.A. Morais; Minerals Engineering; 23, 503 (2010).

11- M. Rozmari, A. Gojmerac and Z. Grahek; Talanta, 80, 362 (2009).

12- L. A. Yousef and T.M.M. Ibrahim; IJSR, 4, 2098 (2015).

13- L. Shapiro and N.W. Brannok; U.S. Geo. Surv., Bulletin, 114, 63 (1962).

14- Z. Merczenko "Spectrophotometric Determination of Elements", John Wiley and Son, New York, U.S.A., 708 (1986).

15- E.M. Jones; Industrial and Engineering Chemistry; 42(11), 2210 (1950). 